\title{
CROSS-BORDER AND LOCAL COOPERATION ON THE ISLAND OF IRELAND: AN ECONOMIC PERSPECTIVE
}

\author{
Stephen Roper
}




\section{CROSS-BORDER AND LOCAL COOPERATION ON THE ISLAND OF IRELAND: AN ECONOMIC PERSPECTIVE

\author{
Stephen Roper
}

Working Papers in British-Irish Studies

No. 57,2006

(also printed as

MFPP working paper no. 7)

Institute for British-Irish Studies

University College Dublin 
IBIS Working Papers

No. 57, 2006

(also printed as

MFPP working paper no. 7)

(C) the author, 2006

ISSN 1649-0304 


\section{ABSTRACT}

\section{CROSS-BORDER AND LOCAL COOPERATION ON THE ISLAND OF IRELAND: AN ECONOMIC PERSPECTIVE}

Cross-border and local cooperation can foster local learning and contribute positively to business performance and social cohesion. This paper considers firms' economic motivation for both types of cooperation around the Irish border. This area, while inevitably impacted by civil unrest in Northern Ireland, shares many of the economic and developmental characteristics of border areas throughout Europe. Simultaneous probit models are used to examine the determinants of cooperation. Overall, around a third of firms in the Republic of Ireland and Northern Ireland engage in local cooperation of some form; around one in six in Northern Ireland and one in twelve in the Republic of Ireland also engage in cross-border cooperation. Proximity to the border, perceived barriers to cross-border cooperation and country uncertainty reduce the incidence of cross-border cooperation rates below that of local cooperation. Cross-border cooperation in Northern Ireland is more common because of small region size and fewer perceived barriers to cross-border cooperation.

\section{Publication information}

Revised version of a paper presented at a study group meting in Newry, 13 September 2005, as part of the programme Mapping frontiers, plotting pathways: routes to North-South cooperation in a divided island.

The programme is funded by the Special EU Programmes Body through the Higher Education Authority over the period 2004-06.

\section{Acknowledgements}

I am grateful to James Williams and Eoin O'Malley in ESRI for making available the data for this study, and to InterTradelreland, the original sponsors of the interview survey. Valuable comments were received from Elizabeth Meehan and Liam O'Dowd. Opinions and mistakes are my own. 


\section{BIOGRAPHICAL INFORMATION}

Stephen Roper is Professor of Business Innovation at Aston Business School, Birmingham, UK. Prior to moving to Aston in 2003, he worked in Northern Ireland and was Assistant Director of the Northern Ireland Economic Research Centre, Belfast. He has published widely on the Irish economies, particularly in the areas of innovation and productivity. His recent work with research partners in ESRI, Dublin, and Queen's University Belfast has focussed on networking and innovation in an allisland context. 



\title{
CROSS-BORDER AND LOCAL COOPERATION ON THE ISLAND OF IRELAND: AN ECONOMIC PERSPECTIVE
}

\author{
Stephen Roper
}

\section{INTRODUCTION}

There is now general agreement that inter-firm cooperation through networks, partnerships and supply-chains can, by facilitating knowledge exchange and reducing transaction costs, contribute both to innovation and company competitiveness (Oerlemans et al, 1998). Dense patterns of "association', alongside links between firms and other support institutions, have also been linked to cluster and regional growth (Cooke and Morgan, 1998). Case-studies of areas with high levels of such interorganisational cooperation have generally also been characterised by social and economic uniformity, geographical contiguity, high levels of social capital (including, in particular, trust), and stable and supportive governance and support institutions (Braczyk et al., 1998). Border regions are often characterised by exactly the opposite conditions: economic discontinuity, low levels of social capital, and governance which is at best divided, and at worst, antagonistic (Mitko et al., 2003). The result can be both a lack of knowledge sharing, diffusion and organisational learning (Petrakos and Tsiapa, 2001), and disproportionately low levels of trade. ${ }^{1}$ In this context, cross-border cooperation can play an important role, countering the structural discontinuity of border regions and generating a potentially positive growth dynamic.

The Irish border shares many of the economic characteristics of border areas in Southeastern Europe identified by Mitko et al. (2003): distance from the main urban centres (Dublin and Belfast), relatively low population densities, a lack of knowledge intensive industries, and weakly developed infrastructure. To these economic and structural issues we have to add the cumulative impact of four decades of civil unrest in Northern Ireland, although as O'Dowd et al (1995: 275) remark: "the exceptionalism of the Irish case should not be overstated ... All borders have a security dimension as they mark the limits of the area in which a particular state can claim to legally monopolise the means of violence ... Given the history of border creation in Europe it seems rather perversely ahistorical to suggest that contested borders are anomalous". Nonetheless, it could be argued that the Irish case is of unique interest, not least because it has been the subject of intense policy and political attention

\footnotetext{
${ }^{1}$ Chionis and Liargovas (2002), for example, examine the level of trade between Greece and South-Eastern Europe (SEE). Over the 1990-99 period they note that exports from Greece to these countries rose $28 \%$ pa, compared to an overall increase in Greek exports of $11 \%$ pa. Similarly, Greek imports from the SEE rose $17 \%$ pa, compared to an overall increase of $12 \%$. Despite these increases they conclude, on the basis of a gravity model that Greece is "undertrading" with all the countries in the reference sample. The ratio of actual over potential exports and imports is around 40 percent on average for both imports and exports. It is also striking that trade with Bulgaria, while still accounting for the largest share of the Greek-Balkan trade, remains below the predicted "normal" level, at 40 percent less for imports and 52 percent less for exports (Chionis and Liargovas, 2002: 28).
} 
over the last decade. In policy terms, the Irish border has been the focus of EU measures (such as INTEREG) alongside more specific and unique policy experiments (such as the Special Support Programme for Peace and Reconciliation). In constitutional terms, political agreements have also been reinforced by specifically targeted institutional developments (such as the cross-border "institutions" and "bodies" created by the Good Friday or Belfast Agreement) aimed to encourage cross-border cooperation and integration (Meehan, 2000).

This paper has two main aims. First, we aim to augment the relatively limited empirical literature on the economic determinants of the probability that firms will engage in cross-border cooperation. In particular, we adopt a transactions cost perspective, and seek to identify those factors which are either specific to, or disproportionately important in, shaping the probability of cross-border interaction relative to more local cooperation. Our second objective is to contribute some positive evidence to the knowledge base relating to the Irish border. Specifically, we focus on identifying differences in the economic determinants of cross-border cooperation in the Republic and Northern Ireland. This provides some insight into current levels of cooperative activity as well as highlighting potential areas for policy intervention. In this sense our study is complementary to that of Tannam (1999), which focuses on governmental, administrative and security cooperation across the border and emphasises the lack of information on cross-border cooperation between businesses (see, for example, her table 8.1).

The argument proceeds as follows. In section 2, we briefly describe the development and characteristics of the Irish border region. This emphasises commonalities with other border areas as well as identifying some of the region's specific characteristics. Section 3 then focuses on our conceptual framework, emphasising the economic benefits for firms of engaging in local and cross-border cooperation. Section 4 describes the data we use and our empirical approach, and section 5 outlines the key empirical results.

\section{THE IRISH BORDER}

The Irish border was created in 1920, separating Northern Ireland, which remains part of the UK, from what is now the Republic of Ireland, the national state. O'Dowd et al. (1995) vividly summarise the result as follows:

A product of the balance of coercion between Britain and nationalist Ireland in 1920, the partition of Ireland installed an erratic and meandering international boundary of $450 \mathrm{~km}$, cross-cutting 1400 agricultural holdings and 180 roads, and bisecting villages and even some individual houses ... Ethno-national minorities were left stranded on either side. Over the next 50 years, this improbable boundary was to endure, and was consolidated by the second world war and the different evolution of both national states. However, the outbreak of the civil rights protests in Northern Ireland in the 1960 s and the ensuing conflict made clear that longevity was not synonymous with legitimacy (O'Dowd et al., 1995: 274). 
More generally, O'Dowd et al. (1995) suggest that the history of the Irish border reflects the continuing tension between economic and supranational (and especially EU) pressures towards integration, and political interest (primarily Northern), or indifference (primarily southern) towards its continued significance (see also Wilson, 2000).

From a more economic perspective, the Irish border shares many of the characteristics which Mitko et al. (2003) suggests are typical of other border or frontier regions, and which may be contributing to their underdevelopment. For example, Mitko et al. (2003: 21) cite low population densities in border areas in Southeastern Europe $^{2}$ which, it has been argued, may lead to a lack of agglomeration economies and a reduction in the scope for local cooperation and learning (Petrakos and Tsiapa, 2001). ${ }^{3}$ Essentially similar points could be made in terms of the Irish border region. Roper (2001), for example, profiles the socio-demography of the region and highlights the rural nature of much of the Irish border area, characterised by low population densities and low levels of employment in professional and technical occupations. ${ }^{4}$

A second characteristic of border regions cited by Mitko et al. (2003) is that they tend to have a peripheral location, away from the economic heartland of the region or country. The Irish border certainly shares this characteristic: "most parts of the Northern Ireland border region are marginal because they are distant from the metropolitan centres of economic and political decision making in Belfast and London" (Wilson, 2000: 3). To the South, an essentially similar point could be made, with development and decision-making in the border counties of the Republic largely detached from that of the Dublin region. ${ }^{5}$ The wider implications for border areas of being "marginal" are less clear, but in an Irish context both Harris and Trainor (1995) and McCartney and Teague (1997), for example, find that innovation was more likely among urban rather than rural firms (see also Petrakos and Tsiapa, 2001).

A third feature of border areas suggested by Mitko et al. (2003) which may constrain economic development is relatively poor infrastructure, something recognised in the priority being given to infrastructure development in the Irish National Development Plan (NDP, 1999) and the EU Operational Programme for the BMW region (BMW Regional Assembly, 2000). Fourth, Mitko et al. (2003) emphasise the discontinuity in regulatory, fiscal and social welfare systems which borders represent, and which may hamper cooperation and collaboration. Fifth, Mitko et al. (2003) emphasise the

\footnotetext{
${ }^{2}$ For example, the Greek border, the Albanian borders with Greece, the Bulgarian borders with Greece and Yugoslavia, the borders of Macedonia with Bulgaria and the borders of Yugoslavia with Bulgaria.

${ }^{3}$ Based on an analysis of the EU transition economies, Petrakos and Tsiapa (2001) conclude that metropolitan locations have structural advantages for firm learning relative to border regions, but argue that networks can help to redress the balance for firms in more peripheral, border areas.

${ }^{4}$ The two exceptions are the Newry-Dundalk area at the extreme East of the border region-part of the Belfast to Dublin corridor-and the Derry-Letterkenny area in the North-West.

${ }^{5}$ Indeed, this is reflected in the split of Ireland between the less prosperous Border, Midlands and West (BMW) region and the Eastern region which has Dublin at its heart.
} 
potential for borders to place limitations on the physical flow of commodities and trade, resulting in distorted markets and locational decisions. Both issues have at various times been important in terms of the Irish border.

Two other factors have also been important in shaping the economic impact of the Irish border: currency fluctuations, and political unrest and violence in Northern Ireland. In terms of currency fluctuations, the emphasis of the debate has largely been on the relative attractiveness for Northern Ireland producers of the Irish market, and the UK market for Irish producers on the basis of the euro-sterling (or, earlier, the Irish pound-sterling) exchange rates. More generally, exchange rate instability across the border-continued by the UK's decision to remain outside the Eurozone-has been seen as having mutually detrimental effects (Bradley and Barry, 1999).

Finally, it is worth considering the impact of unrest in Northern Ireland on the development of the border region, particularly as Mitko et al. (2003: 27) conclude that "countries engaged in ethnic friction and conflict over minorities such as Albania and FYROM, tend to develop less intensive bilateral trade relations". In general terms, the impact of the "troubles" on the Northern Ireland economy are considered to be negative, but the impacts are not necessarily as straightforward as might be imagined. Fielding (2003), for example, suggests that while the troubles had a negative effect on investment in Northern Ireland's manufacturing sector this was more than compensated for by the positive effect of high levels of industrial subsidy, and the attractiveness of Northern Ireland as a production location for companies seeking to emigrate from southern regions of the UK. The net result was that manufacturing employment and investment in Northern Ireland was actually sustained at a higher level than that in the UK as a whole over the 1971-96 period (Fielding, 2003: 514). Arguably, however, the economy of border regions in the North suffered disproportionately from the troubles, such that by the mid-1990s this led McCall and Williamson (2000) to characterise the area as follows: "Economic inertia has been exacerbated by negative social factors including, most notably, a concentration of violent conflict in the region and by the subsequent divisive effect on communities ... on both sides of the border there is a dearth of social capital and associational activity".

The difficulties created by the northern troubles, and more long-lasting issues related to the rurality and peripherality of much of the Irish border region, have attracted considerable policy attention. EU-wide initiatives such as Interreg, initially introduced in 1989, have been supported by specific initiative such as the Special Support Programme for Peace and Reconciliation (SSPPR) - colloquially known as Peace I and Peace II-introduced in 1995 following the republican and loyalist ceasefires (O'Dowd et al., 1995; McCall and Williamson, 2000), as well as elements of the Northern Ireland and the Republic's BMW region operational programmes. The main emphasis of each of these programmes was directed at the social and community sectors, with the aim of building social capital and cohesion and the creation of a cross-border region, in the sense defined by Perkmann (2003) - "a more or less institutionalised collaboration between contiguous sub-national authorities across national borders". A proportion of Peace II money was, however, di- 
rected at promoting cross-border business activity, a measure implemented by Cooperation Ireland. ${ }^{6}$

In general terms therefore, we would echo O'Dowd et al. (1995) in their view that "the exceptionalism of the Irish case should not be overstated". Despite past security issues the economic context of the Irish border shares many of the characteristics of border regions elsewhere (Mitko et al., 2003). What is clear, however, and perhaps more exceptional, is the amount of political capital invested by the UK and Irish governments, and the EU, in the promotion of cross-border dialogue and cooperation. For individual businesses, however, the decision of whether or not to engage in cross-border cooperation-or indeed any other form of cooperation-will relate not to these wider political issues but to the costs and benefits of such activity. This decision is the focus of the next section.

\section{CONCEPTUAL FRAMEWORK}

Our objective here is to delineate a framework which describes firms' key motivations for engaging in cooperation, and suggests where the factors which determine the probability of local and cross-border cooperation may differ. In general terms, we argue that firms' willingness to engage in cooperation will depend on their assessment of the perceived costs and benefits. ${ }^{7}$ This focuses attention on firms' access to productive resources, risk reduction and cost reduction as the key determinants of cooperation, moderated in the case of cross-border cooperation by potential gains from market access, and the distance from potential partners (figure 1). In addition, we envisage the choice to engage in cross-border and/or local cooperation as simultaneous, suggesting the potential for potential substitute or complementary relationships between the two activities (figure 1). In fact, what we observe is firms' actual participation in cross-border (cxb) or local cooperation (cloc) which we interpret in structural terms as follows:

$$
\begin{aligned}
& c x b_{i}=\alpha_{1}+\beta_{1} x_{1 i}+\gamma_{1} \operatorname{cloc}_{i}+\varepsilon_{1 i} \\
& \operatorname{cloc}_{i}=\alpha_{2}+\beta_{2} x_{2 i}+\gamma_{2} \operatorname{cxb}_{i}+\varepsilon_{2 i}
\end{aligned}
$$

Where $x_{1 i}$ and $x_{2 i}$ are vectors of possible determinants of cooperation.

\footnotetext{
${ }^{6}$ For example, McCall and Williamson (2000: 407-8) cite Co-operation Ireland support for cross-border business link-ups including a cooperative project between and knitwear company in County Down and another in County Donegal ( $£ 3000)$ and a cross-Border venture by three engineering companies $(£ 77,000)$.

${ }^{7}$ Buckley and Chapman (1997: 143) summarise the situation as follows: "Managerial perceptions matter, and transaction costs cannot be quantified or measured separately from these perceptions. Managers undertake a conscious (not random) selection from among arrays of potential transaction costs, and among the most important transaction costs are those which are avoided by this process. From the observer's point of view, transaction costs are thus difficult to measure in any objective fashion".
} 


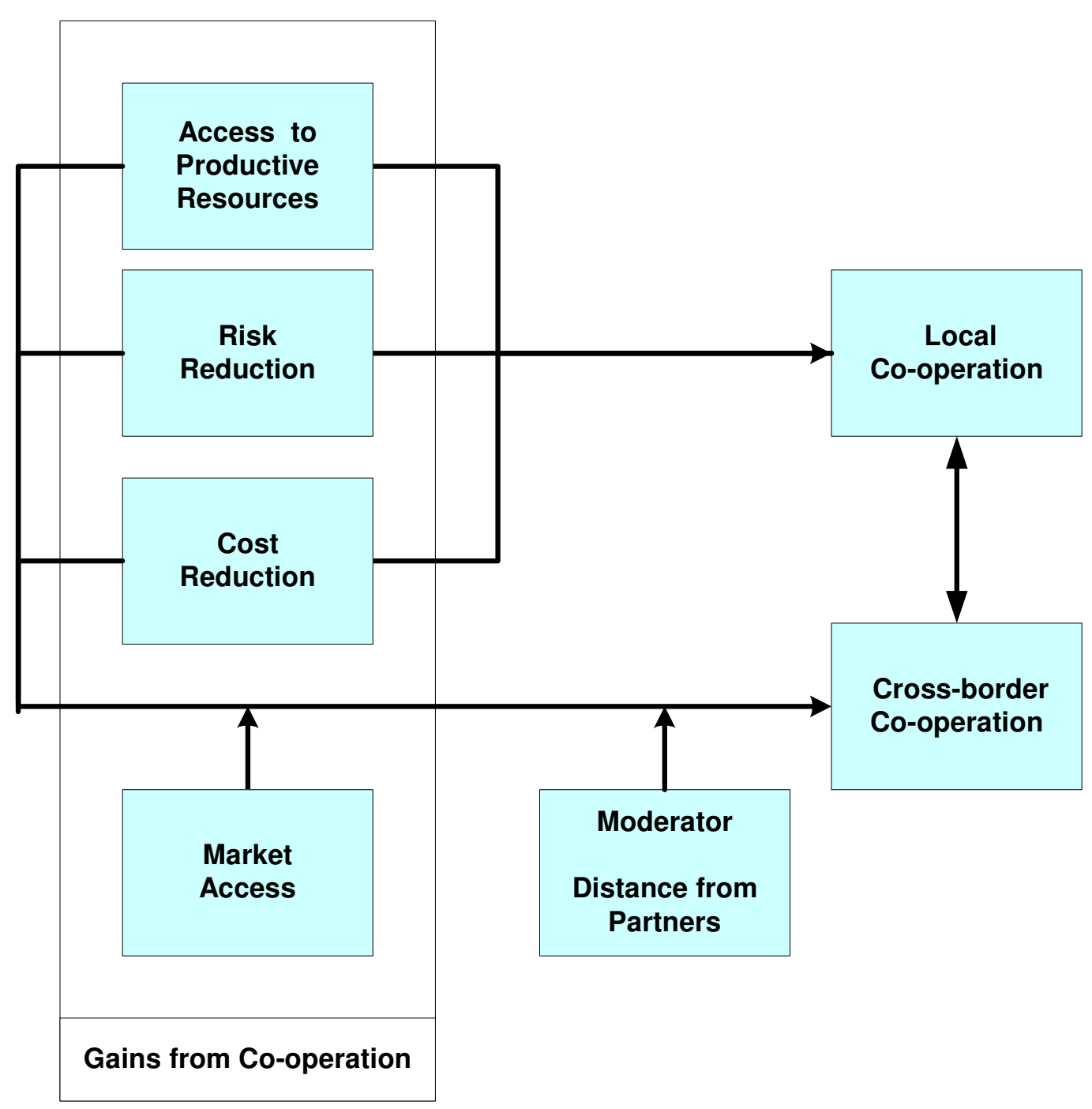

Figure 1: Structural relationships determining local and cross-border cooperation

More specifically, we argue that firms will engage in cooperation where it is more cost-effective to acquire resources or assets through a cooperative agreement or arrangement than through a standard market transaction or internal development. ${ }^{8}$ Cooperation may therefore be resource-enhancing or enriching, allowing firms to focus on their core competencies while also maximising returns from their own asset base. We therefore suggest that both local and cross-border cooperation will be positively influenced by the perceived benefits of the relationship, and discouraged by potential difficulties such as those related to asset specificity and the possibility of lock-in. Hence:

\footnotetext{
${ }^{8}$ Buckley and Chapman (1998) employ a social anthropology approach, and find that while transaction costs play an important role in shaping cooperative arrangements there is little attempt by managers to make any objective measurement of issues such as asset specificity or uncertainty. Where such issues are considered, they find that the emphasis is on linguistic rather than numerical expressions of transaction costs, with frequent reference to issues such as trust and commitment.
} 
H1: Expected returns-The probability of both local and cross-border cooperation will be related equally strongly to the expected net returns from the activity.

In the case of cross-border cooperation the expected returns may, however, be moderated or shaped by proximity to the border (see figure 1). Although, in the context of cooperation between Austrian firms with Central and Eastern Europe, Huber (2003) finds only small distance effects on the probability of cooperation, Mitko et al. (2003) find more significant distance effects, finding that South-Eastern Europe firms located near the border are more likely to develop cross-border linkages than the national average (see also Petrakos and Tsaipa, 2001). We therefore suggest:

H2: Distance effects-The probability of cross-border cooperation will be negatively related to distance from the border reflecting distance effects on the expected returns from cross-border cooperation. No distance effects are anticipated on the incidence of local cooperation.

The potential gains from cooperation, however, will depend not only on market conditions but will also be contingent on the characteristics and resources of the firm. Huber (2003), for example suggests that small firms are more resource constrained, may have more to gain from cooperation, but may have less specialist managerial resource, to enable an appropriate level of investment. Other evidence on the functional capacity of firms also suggests the inter-relation between firms' internal resources and external cooperation, although evidence on the nature of this relationship remains somewhat ambiguous. ${ }^{9}$ The possibility that cooperation is used to access resources or knowledge, however, suggests a substitution of external investment (i.e. cooperation) for internal resources, a relationship we expect to apply equally strongly to both local and cross-border linkages. An essentially similar argument suggests the potential for substitution between cross-border and local cooperation as sources of resources or knowledge. Hence: ${ }^{10}$

H3: Resource availability -The probability of both local and cross-border cooperation will be negatively related to the strength of firms' internal resource base.

H4: Substitution-The probability of local cooperation will be negatively related to the probability of cross-border cooperation and vice-versa.

In addition to the potential cost savings which might result from cooperation, it has been suggested that effective cooperation may also help firms to offset, or respond more effectively to, market ("primary") uncertainty. ${ }^{11}$ Cross-border cooperation, in particular, may provide a mechanism by which firms can hedge uncertainty in either the Northern Ireland or Republic of Ireland markets. We therefore suggest that mar-

\footnotetext{
${ }^{9}$ On the relationship between internal and external R\&D, for example, see Veugelers and Cassiman, 1999; Love and Roper, 1999, 2001; Cassiman and Veugelers, 2002.

${ }^{10}$ The same substitute relationship is clearly implicit in the resource-based view, as the firm focuses on developing "core" and out-sourcing "non-core" competencies (Principe, 1997; Takeishi 2001).

${ }^{11}$ Advantages may also arise from the development by partner organisations of routines designed to reduce secondary uncertainty, i.e. the risk that managers within the partner organisations will not co-ordinate knowledge in the optimum fashion (Koopmans, 1957; Buckley and Carter, 1999)
} 
ket uncertainty is likely to have a differential effect on the probability of local and cross-border cooperation. Hence:

H5: Market uncertainty -The probability of cross-border cooperation is likely to be more strongly, and positively, influenced by market uncertainty than the probability of engaging in local cooperation.

Cross-border cooperation will, however, raise other issues related to uncertainty which will are less likely to arise in local cooperation, i.e. country uncertainty (Reddy et al., 2002: 763-764). At base, this reflects firms' asymmetric information about their home market and the cross-border market, which may increase the perceived risk of engaging in cross-border cooperation. In the context of the Irish border, as in other border areas characterised by "ethnic friction" (Mitko et al., 2003), it may also be argued that, for at least some companies, the economic uncertainty implicit in cross-border cooperation may be exacerbated by a lack of trust linked to sociopolitical tensions. Following Aulakh et al. (1996), low levels of trust are likely to reduce the incidence of cross-border partnerships, particularly where market conditions are uncertain. This suggests:

H6: Country uncertainty - The probability of cross-border cooperation is likely to be more strongly, and negatively influenced by country uncertainty than the probability of engaging in local cooperation.

\section{DATA AND METHODS}

The data used here was collected by personal interviews with senior managers in firms throughout the Republic and Northern Ireland in 2003 and relates to firms' activities over the 2000-02 period (Williams et al., 2004). The target group for the surveys were firms or enterprises-as opposed to establishments or plants-employing 10 or more people at the time of the survey. The surveys covered firms in all sectors and were designed to be representative of the population of firms in each area. In total, data was provided by 824 firms in the Republic and 595 firms in Northern Ireland. This group of respondents represent around $7.2 \%$ of firms in the target group in the Republic and around $9.9 \%$ of those in Northern Ireland. Following Williams et al. (2004) we weight survey responses in the analysis to give regionally representative results. ${ }^{12}$

Data was collected using the same survey instrument in the Republic and Northern Ireland, with some minor variations to reflect institutional and geographic differences. Firms were asked in particular about cooperation activities during 2002, and whether these were local (within the Republic or Northern Ireland) or cross-border. Participation in nine specific types of cooperative activity was recorded (table 1):

\footnotetext{
${ }^{12}$ Weights were based on a population structure comprising sector (10 categories); size of company (two categories) and area (three categories in the Republic and three in Northern Ireland). This gave a total of 60 cells for re-weighting purposes in each jurisdiction. In Ireland, the population structure was based on data from the Census of Industrial Production and Annual Services Enquiry. In Northern Ireland, the population structure was provided by the survey company undertaking the original fieldwork.
} 
1. Collaboration on research and development $(R \& D)$ or the development of standards.

2. Purchase of raw materials, services or equipment as part of a larger group.

3. Participate in any joint marketing effort or share the cost of trade shows with other companies.

4. Bid on contracts or prepare joint tenders with other companies.

5. Share any technical capabilities with other companies.

6. Cooperate with other companies in meeting the design or quality requirements of customers.

7. Cooperate with other companies in staff training programmes.

8. Participate in joint distribution network with other company.

9. Cooperate with other companies in the production of your goods or services.

Across the whole range of activities $15.4 \%$ of Northern Ireland firms, and $8.1 \%$ of firms in the Republic were engaged in cross-border cooperation, while about a third of companies were engaged in local cooperation (see table 1 ). ${ }^{13}$ It is hard to compare these levels of cooperative activity will those elsewhere given differences in the size of geographical regions. It is striking, however, that the levels of local cooperation identified here (31-32\%) are broadly in line with the proportion of Austrian firms undertaking local cooperation (35.6\%) found by Huber (2003: 950, table 1).

To reflect the potential benefits to firms of cooperation we include two variables reflecting firms' perceptions of high labour and energy costs. We also include here two variables relating to the (non-specific) barriers which firms perceived in developing cross-border cooperation, and firms' perception of high local business tax rates. Responses to this question may reflect the marked difference between corporation tax rates in Northern Ireland (30\%) and the Republic (12\%), creating potential incentives for cross-border cooperation and integration to allow transfer pricing.

To reflect distance effects we consider a series of dummy variables which reflect firms' distance (in miles) from the border by the shortest road route. Resource availability is reflected by two variables reflecting whether the firm had in-house $R \& D$ and had faced any labour shortages over the previous year. Variables reflecting firm size are also included to reflect the stronger resource base of larger firms. Market uncertainty is reflected in two variables reflecting the strength of local competition and two other dummy variables indicating whether or not firms perceived unfair competition in their home market from local or international competitors. Country uncertainty is reflected in a variable reflecting firms' perception of exchange rate difficulties, and two variables reflecting the extent of firms' cross-border sales and the number of years for which they had been engaged in cross-border trading. In addition, we include in the models a range of control variables relating to sectoral differences, exporting outside the Republic and firms' sales growth over the 200002 period.

\footnotetext{
${ }^{13}$ In fact, given the relative sizes of the northern and southern economies this ratio is what we should expect if all cross-border links were on a dyadic basis.
} 
Table 1: Proportion of firms engaging in local and cross-border cooperation

\begin{tabular}{|c|c|c|c|c|}
\hline Focus of Cooperation & $\begin{array}{l}\text { Type of } \\
\text { Cooperation }\end{array}$ & $\begin{array}{l}\text { Northern } \\
\text { Ireland (\%) }\end{array}$ & $\begin{array}{l}\text { Republic of } \\
\text { Ireland (\%) }\end{array}$ & All firms \\
\hline \multirow{2}{*}{$\begin{array}{l}\text { Collaboration on Research \& Develop- } \\
\text { ment or the development of standards }\end{array}$} & Local & 7.2 & 10.1 & 9.1 \\
\hline & Cross-Border & 3.0 & 2.4 & 2.6 \\
\hline \multirow{2}{*}{$\begin{array}{l}\text { Purchase of raw materials, services or } \\
\text { equipment as part of a larger group }\end{array}$} & Local & 10.3 & 9.1 & 9.5 \\
\hline & Cross-Border & 5.9 & 2.3 & 3.6 \\
\hline \multirow{2}{*}{$\begin{array}{l}\text { Participate in any joint marketing effort or } \\
\text { share the cost of trade shows with other } \\
\text { companies }\end{array}$} & Local & 7.0 & 11.2 & 9.8 \\
\hline & Cross-Border & 3.4 & 1.8 & 2.4 \\
\hline \multirow{2}{*}{$\begin{array}{l}\text { Bid on contracts or prepare joint tenders } \\
\text { with other companies }\end{array}$} & Local & 6.4 & 5.8 & 6.0 \\
\hline & Cross-Border & 4.0 & 1.0 & 2.0 \\
\hline \multirow{2}{*}{$\begin{array}{l}\text { Share any technical capabilities with other } \\
\text { companies }\end{array}$} & Local & 8.3 & 6.3 & 7.0 \\
\hline & Cross-Border & 2.9 & 2.0 & 2.3 \\
\hline \multirow{2}{*}{$\begin{array}{l}\text { Cooperate with other companies in meet- } \\
\text { ing the design or quality requirements of } \\
\text { customers }\end{array}$} & Local & 11.1 & 12.3 & 11.9 \\
\hline & Cross-Border & 3.6 & 2.2 & 2.7 \\
\hline \multirow{2}{*}{$\begin{array}{l}\text { Cooperate with other companies in staff } \\
\text { training programmes }\end{array}$} & Local & 13.1 & 12.6 & 12.8 \\
\hline & Cross-Border & 2.4 & 0.8 & 1.4 \\
\hline \multirow{2}{*}{$\begin{array}{l}\text { Participate in joint distribution network with } \\
\text { other company }\end{array}$} & Local & 4.7 & 4.7 & 4.7 \\
\hline & Cross-Border & 2.8 & 0.9 & 1.5 \\
\hline \multirow{2}{*}{$\begin{array}{l}\text { Cooperate with other companies in the } \\
\text { production of your goods or services }\end{array}$} & Local & 10.9 & 9.2 & 9.8 \\
\hline & Cross-Border & 5.1 & 2.4 & 3.3 \\
\hline \multirow[t]{2}{*}{ All forms of cooperation } & Local & 32.1 & 31.5 & 31.7 \\
\hline & Cross-Border & 15.4 & 8.1 & 10.6 \\
\hline
\end{tabular}

Source: Williams et al., 2004.

Two issues arise in the empirical estimation of equation 1. First, as we regard the decision to engage in local and cross-border cooperation as simultaneous, and as we observe only the actual ex-post decisions to engage in cooperation, this suggests a simultaneous probit formulation, as discussed by Madalla (1983: 246). Appropriate estimation for this model is in two-stages, estimating first reduced form models, and then substituting the fitted values produced into the structural equation estimates (see Madalla, 1983: 246-247). Derivation of the variance/covariance matrices for the structural equations is then standard, correcting for correlation be- 
tween equation errors. A second issue which arises in the estimation is the relatively "unbalanced" nature of the sample, with only a small proportion of firms engaging, in particular, in cross-border cooperation. In this situation, standard measures of "fit" for probit models are relatively poor indicators of model quality, and Greene (2003) discusses the potential for using alternative "limits" in the predicted probabilities in this type of situation, depending on the empirical objective, i.e. the overall predictive power of the model, or its ability to identify participants in, say, cross-border cooperation. We return to this issue in the next section.

\section{EMPIRICAL RESULTS}

Simultaneous probit models of the probability of engaging in local and cross-border cooperation were estimated separately for the Republic and Northern Ireland (table 2). Each model included a series of variables chosen to reflect each of the hypotheses outlined earlier together with a series of controls (for example, exporting, growth, sectoral dummy variables). Overall, the equation chi-square statistics suggest the validity of the models. Using conventional limits for the predicted probabilities (i.e. 0.5), however, the models were poor at identifying those firms engaging in both local and cross-border cooperation despite high levels of correct predictions. This issue is discussed in detail in section 5.2 following a review of the evidence for each of the hypotheses identified earlier.

\subsection{Determinants of cooperation}

Consistent with our argument that firms' participation in cooperative relationships will depend on their assessment of the costs and benefits of the activity, Hypothesis 1 suggests that both local and cross-border cooperation will be related to the perceived returns. We find no consistent evidence, however, that expected returns significantly influence the probability of local cooperation in Northern Ireland or the Republic (table 2). In the Republic, however, there is some evidence that perceived barriers to cross-border cooperation may be encouraging firms to substitute local cooperation. This may reflect the historical difficulties of cross-border trading due to the Northern Ireland troubles underlying the discussion in O'Dowd et al. (1995) and Wilson (2000). Cost factors also seem to be important in shaping firms' participation in cross-border participation, with high labour costs discouraging cross-border cooperation by firms located in Northern Ireland but encouraging cross-border cooperation by firms in the Republic. This is consistent with an interpretation that crossborder labour cost differentials-higher labour costs in the Republic-are attracting southern firms to engage in cross-border cooperation but discouraging northern firms from forming links to firms in the Republic. Similarly, perceptions of high energy costs are also discouraging Northern Ireland firms from engaging in crossborder cooperation, although no such effect is evident in the Republic. Less easy to explain is the result that perceptions of high corporation tax rates are encouraging firms in the Republic to engage in cross-border cooperation when, as indicated earlier, corporation tax rates are actually lower in the Republic. As expected, then our results suggest some support for hypothesis 1, with higher costs, or lower expected returns discouraging, cross-border cooperation. 
Table 2: Simultaneous probit models of cross-border and local cooperation

\begin{tabular}{|c|c|c|c|c|c|c|c|c|}
\hline & \multicolumn{2}{|c|}{$\begin{array}{l}\text { Northern Ireland } \\
\text { Cross-border }\end{array}$} & $\begin{array}{l}\text { Local } \\
\text { Coeff }\end{array}$ & Z score & \multicolumn{2}{|c|}{ Republic of Irelan } & $\begin{array}{l}\text { nd } \\
\text { Local } \\
\text { Coeff }\end{array}$ & if Z score \\
\hline $\begin{array}{l}\text { Expected Returns } \\
\text { Barriers to cooperation } \\
\text { High Labour Costs } \\
\text { High Energy Costs } \\
\text { High Tax Rates }\end{array}$ & $\begin{array}{r}-0.253 \\
-0.289 \\
0.172\end{array}$ & $\begin{array}{r}-1.717 \\
-1.986 \\
1.159\end{array}$ & $\begin{array}{r}0.110 \\
-0.072 \\
0.180 \\
-0.121\end{array}$ & $\begin{array}{r}0.780 \\
-0.474 \\
1.185 \\
-0.839\end{array}$ & $\begin{array}{l}0.372 \\
0.403\end{array}$ & $\begin{array}{l}1.547 \\
1.759\end{array}$ & $\begin{array}{l}0.387 \\
0.062\end{array}$ & $\begin{array}{l}2.557 \\
0.377\end{array}$ \\
\hline $\begin{array}{l}\text { Distance Effects } \\
\text { Border: } 1-10 \text { miles } \\
\text { Border: } 11-30 \text { miles } \\
\text { Border: } 31-60 \text { miles }\end{array}$ & $\begin{array}{l}-0.359 \\
-0.644 \\
-0.398\end{array}$ & $\begin{array}{l}-1.138 \\
-2.453 \\
-1.648\end{array}$ & $\begin{array}{l}-0.322 \\
-0.143\end{array}$ & $\begin{array}{l}-1.202 \\
-0.712\end{array}$ & $\begin{array}{l}0.357 \\
0.221\end{array}$ & $\begin{array}{l}2.245 \\
1.176\end{array}$ & $\begin{array}{l}0.145 \\
0.230\end{array}$ & $\begin{array}{l}0.989 \\
1.591\end{array}$ \\
\hline $\begin{array}{l}\text { Resource Availability } \\
\text { R\&D in the firm } \\
\text { Size: } 20-49 \text { employees } \\
\text { Size: } 50-99 \text { employees } \\
\text { Size: } 100 \text { plus employees } \\
\text { Labour Shortages }\end{array}$ & $\begin{array}{r}-0.481 \\
0.630\end{array}$ & $\begin{array}{r}-2.745 \\
2.793\end{array}$ & $\begin{array}{r}0.685 \\
0.336 \\
-0.095 \\
0.093 \\
-0.133\end{array}$ & $\begin{array}{r}4.759 \\
1.743 \\
-0.533 \\
0.286 \\
-1.063\end{array}$ & $\begin{array}{r}0.394 \\
-0.403 \\
0.182 \\
-0.076\end{array}$ & $\begin{array}{r}2.022 \\
-2.333 \\
\\
1.070 \\
-0.519\end{array}$ & $\begin{array}{r}0.108 \\
-0.130\end{array}$ & $\begin{array}{r}0.774 \\
-1.330\end{array}$ \\
\hline $\begin{array}{l}\text { Substitution } \\
\text { Local Cooperation } \\
\text { Cross-Border Co-op. }\end{array}$ & 0.259 & 1.523 & 0.380 & 1.177 & 0.302 & 0.753 & 0.192 & 0.897 \\
\hline $\begin{array}{l}\text { Market Uncertainty } \\
\text { Low number of competitors } \\
\text { High number of competitors } \\
\text { Unfair local competition } \\
\text { Unfair international competition }\end{array}$ & 0.265 & 1.756 & $\begin{array}{r}-0.136 \\
0.286 \\
-0.253\end{array}$ & $\begin{array}{r}-0.877 \\
\\
1.993 \\
-1.708\end{array}$ & -0.226 & -1.490 & $\begin{array}{r}0.248 \\
-0.276\end{array}$ & $\begin{array}{r}2.231 \\
-2.124\end{array}$ \\
\hline $\begin{array}{l}\text { Country Uncertainty } \\
\text { Cross-border Selling (years) } \\
\text { Sales in other area (\%) } \\
\text { Exchange Rates }\end{array}$ & $\begin{array}{l}0.025 \\
0.867\end{array}$ & $\begin{array}{l}4.322 \\
5.976\end{array}$ & $\begin{array}{l}-0.008 \\
-0.002 \\
-0.248\end{array}$ & $\begin{array}{l}-0.776 \\
-0.503 \\
-0.804\end{array}$ & $\begin{array}{l}0.013 \\
0.022\end{array}$ & $\begin{array}{l}4.169 \\
5.375\end{array}$ & $\begin{array}{r}-0.006 \\
0.001\end{array}$ & $\begin{array}{r}-1.331 \\
0.090\end{array}$ \\
\hline $\begin{array}{l}\text { Controls } \\
\text { Sales outside Island (\%) } \\
\text { Sales increased } \\
\text { Sales decreased } \\
\text { Sector: Construction } \\
\text { Sector: Retail } \\
\text { Sector: Property, Bus. Services } \\
\text { Sector: Hospitality } \\
\text { Sector: Personal Services } \\
\text { Constant }\end{array}$ & $\begin{array}{r}0.003 \\
0.188 \\
-0.386 \\
0.427 \\
-0.374 \\
-0.197\end{array}$ & $\begin{array}{r}0.872 \\
1.179 \\
-1.470 \\
1.718 \\
-2.021 \\
-0.854\end{array}$ & $\begin{array}{r}-0.049 \\
0.281 \\
0.193 \\
0.180 \\
0.324\end{array}$ & $\begin{array}{r}-0.202 \\
1.014 \\
1.023 \\
0.869 \\
1.540\end{array}$ & $\begin{array}{r}0.683 \\
-2.216\end{array}$ & $\begin{array}{r}0.873 \\
-5.898\end{array}$ & $\begin{array}{r}-0.002 \\
0.122 \\
0.333 \\
-0.127\end{array}$ & $\begin{array}{r}-0.747 \\
0.983 \\
2.385 \\
-0.448\end{array}$ \\
\hline $\begin{array}{l}\text { N } \\
\text { Log Likelihood }\end{array}$ & & $\begin{array}{r}574 \\
-189.61\end{array}$ & & $\begin{array}{r}574 \\
-318.87\end{array}$ & & $\begin{array}{r}790 \\
-176.45\end{array}$ & & $\begin{array}{r}790 \\
-464.22\end{array}$ \\
\hline $\begin{array}{l}\text { Chi-square } \\
\text { HL Chi-square }\end{array}$ & $\begin{array}{r}107.20( \\
6.11(\end{array}$ & $\begin{array}{l}\mathrm{D}=0.000) \\
\mathrm{o}=0.634)\end{array}$ & $\begin{array}{l}82.87(p \\
15.58(p\end{array}$ & $\begin{array}{l}=0.000) \\
=0.049)\end{array}$ & $\begin{array}{l}94.33(p \\
13.49(p\end{array}$ & $\begin{array}{l}\mathrm{D}=0.000) \\
\mathrm{D}=0.958)\end{array}$ & $\begin{array}{l}65.75(\mathrm{p}= \\
12.53(\mathrm{p}=\end{array}$ & $\begin{array}{l}\mathrm{o}=0.000) \\
\mathrm{o}=0.129)\end{array}$ \\
\hline $\begin{array}{l}\text { Estrella } \\
\text { Correct Predictions } \\
\text { No cooperation (\%) } \\
\text { Cooperation (\%) }\end{array}$ & & $\begin{array}{l}0.174 \\
0.855 \\
0.975 \\
0.183\end{array}$ & & $\begin{array}{l}0.141 \\
0.707 \\
0.900 \\
0.298\end{array}$ & & $\begin{array}{l}0.060 \\
0.910 \\
0.990 \\
0.058\end{array}$ & & $\begin{array}{l}0.053 \\
0.688 \\
0.919 \\
0.203\end{array}$ \\
\hline
\end{tabular}

Source: Derived from Williams et al., 2004. 
Hypothesis 2 relates to the effect of distance from the border on firms' propensity to engage in cross-border cooperation. Following Huber (2003), we expect firms more distant from the border to be less likely to engage in cross-border cooperation, but that firms' location will have no effect on the extent of local cooperation. In table 2, where the omitted reference group comprises firms located more than 60 miles from the border, this suggests that we expect to find positive coefficients in the crossborder cooperation model. In the Republic, our evidence is consistent with this expectation; the distance variables are seen to have no significant effects on the probability that firms will engage in local cooperation; distance has significant effects on cross-border cooperation; and, cross-border cooperation is significantly more likely among firms within 10 miles of the border (table 2). For Northern Ireland we also find no evidence that distance from the border influences the probability of local cooperation. The pattern of distance effects for Northern Ireland is not as anticipated, however, with distance from the border having no consistent or significant effect on participation in cross-border cooperation across the whole range of dummy variables reflecting distance, a reflection perhaps of the relatively small size of Northern Ireland itself. There is, however, some evidence of a decline in firms' propensity to engage in cross-border participation between those firms located 1-10 miles from the border and those located 11-30 miles away (table 2). This provides partial support for the type of distance effects hypothesised in Northern Ireland. In summary, therefore, we conclude that hypothesis 2 is supported, with distance effects both having more effect on cross-border cooperation than local cooperation, and evidence of a gradient of propensity to participate in cross-border cooperation related to distance from the border.

Hypothesis 3 relates to the strength of firms' resource base, and argued that the probability of cooperation-both local and cross-border-will be negatively related to the strength of firms' resource base. In the estimation, we would therefore expect larger firms-typically regarded as having a stronger internal resource base-to have less need for either form of cooperation. ${ }^{14}$ In fact, we observe a more complex pattern with three key elements. First, the probability of local, and in the Republic, cross-border, cooperation is positively related to situations where firms have inhouse $R \& D$, and only weakly related to other resource availability (such as labour shortages, table 2). This suggests the complementarity of in-house R\&D and external cooperation, reflecting other studies which have suggested the role of $R \& D$ as an important element of firms' absorptive capacity (Cohen and Levinthal, 1989, 1990). Veugelers and Cassiman (1999), for example, in their analysis of Belgian data suggest that firms undertaking in-house $R \& D$ benefited more from external information sources than companies which had no in-house R\&D activity. Cassiman and Veugelers (2002) also emphasise the complementarity between internal and external R\&D activity, and demonstrate that firms engaging in both activities introduce more innovative products than firms engaged in either external or internal R\&D alone. Second, contrary to our expectations, there is little evidence of any significant relationship between firm size and propensity to engage in local coopera-

\footnotetext{
14 Hewitt-Dundas et al. (2002), for example, identify significantly higher adoption rates for a range of advanced manufacturing techniques among larger and externally-owned plants in the Republic of Ireland.
} 
tion. Third, there is evidence of a firm size effect on the probability of engaging in cross-border cooperation but this is non-linear, having a "U" shape-the probability of engaging in cross-border cooperation is greatest for small (10-20) and larger (100 plus employee) companies. One possible explanation for this non-linear pattern is that the motives for cross-border cooperation may differ between larger and smaller firms and that these motives may be differently related to resource availability. Our survey data, however, provides no information on firms' motives for cross-border cooperation. We do, however, as in table 1, have information on the type of cooperation in which firms engage which we might expect to differ between larger and smaller firms if their motives for cooperation were different. In fact, there are no significant differences in the proportion of small (10-20) and larger (100 plus employee) firms engaging in any of the different forms of cooperation. ${ }^{15}$

Hypothesis 4 relates to the potential for substitution or complementary relationships between local and cross-border cooperation. Substitution may arise, for example, if firms treat local and cross-border cooperation as alternative methods of knowledge gathering (Love and Roper, 1999, 2001). Complementarity is perhaps more likely to relate to the internal costs of cooperation where firms achieve economies of scope in the management of external relationships (Cassiman and Veugelers, 2002) or through undertaking one form of cooperation gain in terms of absorptive capacity (Cohen and Levinthal, 1989). In fact, our evidence points to a weak complementary relationship between local and cross-border cooperation with positive but insignificant coefficients on the substitution terms in table 2. The implication is that firms in both the Republic and Northern Ireland are deriving some enhanced benefit from cross-border cooperation if they are also involved in local cooperation and viceversa. In neither case, however, is this beneficial effect particularly strong.

Hypothesis 5 relates to local market uncertainty and suggests that the more uncertain or competitive the local market, the more likely it is that firms will engage in cooperation, both local and cross-border. In fact, we do find that market uncertainty has significant effects on each type of cooperative activity. Our data suggests that firms respond differently to local market competition originating from local and externally-owned companies. In each case, however, a firm's response to competitive pressure is to seek to develop cooperation with its competitors-either at home or abroad. For example, market uncertainty due to competition from local firms tends to encourage local cooperation in both Northern Ireland and the Republic. Market uncertainty due to local market competition from foreign competitors, however, ac-

\footnotetext{
${ }^{15}$ Comparing the proportions of small and larger firms undertaking each form of cooperation suggests the following test statistics for the whole sample: collaboration on research and development or the development of standards, $t=-0.585, p=0.558$ ); purchase of raw materials, services or equipment as part of a larger group, $t=-0.721, p=0.471$ ); participate in any joint marketing effort or share the cost of trade shows with other companies, $t=-0.812, p=0.416$ ); bid on contracts or prepare joint tenders with other companies, $t=0.337, p=$ 0.735 ); share any technical capabilities with other companies, $t=-0.461, p=0.644)$; cooperate with other companies in meeting the design or quality requirements of customers, $t=-0.695, p=0.487$ ); cooperate with other companies in staff training programmes, $t=0.643, p=0.520$ ); participate in joint distribution network with other company, $\mathrm{t}=-1.150, \mathrm{p}=0.250$ ); co-operate with other companies in the production of your goods or services, $\mathrm{t}=0.689, \mathrm{p}=0.490$ ); all forms of cooperation, $\mathrm{t}=-0.148, \rho=0.882$ ).
} 
tually discourages local cooperation but has a positive and significant effect on cross-border cooperation, at least in the Republic (table 2).

Hypothesis 6 relates to country uncertainty, which is linked to currency fluctuations or the uncertainty implicit in trading in a market which is not a firm's home market (Reddy et al., 2002). Country uncertainty, the hypothesis suggests, is likely to have a more negative effect on cross-border cooperation than local cooperation. Variables included in the models will directly reflect country uncertainty (exchange rates), and the reduction in uncertainty due to learning effects due to firms' knowledge of the other Irish jurisdiction through their prior experience of cross-border trading. In the estimation, we find strong support for the structural element of the hypothesis with none of the country uncertainty variables having any significant impact on local cooperation (table 2). As expected, however, firms with a history of cross-border trading - and therefore more knowledge about market conditions in the other Irish jurisdiction-are more likely than others to be engaging in cross-border cooperation. Contrary to expectations, however, we find a strong positive effect from exchange rate uncertainty on cross-border cooperation in both the Republic and Northern Ireland, The suggestion is that far from discouraging cross-border cooperation, firms may be using cross-border cooperation to hedge against currency fluctuations by balancing their exposure to northern and southern markets.

\subsection{Identifying cooperating firms}

As indicated earlier, convention in binomial probit estimation is to use 0.5 as the cutoff, or limit, for allocating the predicted values to either the "0" or "1" categories. In situations like that considered here, however, where the proportion of firms participating in cross-border and local cooperation is low, this convention generally tends to lead to low levels of correct classification for those firms engaging in cooperation. This is very evident in table 2, where the models identify $6-30 \%$ of cooperating firms, compared to $90-99 \%$ of non-cooperating firms. To improve the proportion of cooperating firms identified, one possibility is to change the limit values (see the discussion in Greene, 2003: 685-6). This is considered in table 3, which summarises the results of this procedure, reporting the overall percentage of correct predictions and each model's ability to correctly identify firms participating in cross-border or local cooperation. ${ }^{16}$ What is immediately clear is that the overall percentage of correct predictions and models' ability to correctly identify firms participating in either local or cross-border cooperation are inversely related. For example, for Northern Ireland a limit of 0.1 results in $86.2 \%$ of all firms engaging in cross-border cooperation being correctly identified, falling to $44.8 \%$ with a limit of 0.3 . The same change in the limit increases the overall percentage of correct predictions from $61.8 \%$ to $84.5 \%$. Choosing limit values to maximise the percentage of firms engaging in cooperation therefore generates false "positives" reducing the overall predictive accuracy of the models (see also the case cited by Greene, 2003: 685-686).

\footnotetext{
${ }^{16}$ In fact, as the estimates derived from the first stage reduced forms are the fitted values it is only at the second stage - the structural form estimation - that the different limit values have any impact on the estimation. This also means that the impact of the alternative limit values on the two equations is independent.
} 
Table 3: Predictive accuracy with alternative limit values

\begin{tabular}{|c|c|c|}
\hline Limit & Cross-border Cooperation & Local Cooperation \\
\hline & $\begin{array}{ll}\text { Overall } & \text { Cross-border } \\
\% \text { Correct } & \% \text { Correct }\end{array}$ & $\begin{array}{ll}\text { Overall } & \text { Local } \\
\% \text { Correct } & \% \text { Correct }\end{array}$ \\
\hline
\end{tabular}

\section{A. Northern Ireland}

0.1

0.2

0.3

0.4

0.5

0.6

0.7

0.8

0.9

\section{B. Republic of Ireland}

0.1

0.2

0.3

0.4

0.5

0.6

0.7

0.8

0.9

61.8
78.9
84.5
85.5
85.5
85.5
85.2
85.4
85.2

73.2

85.7

89.1

90.6

91.0

91.3

91.3

91.4

91.5

86.2
65.5
44.8
28.7
18.4
11.5
5.7
3.4
2.3

60.3

29.4

22.1

10.3

5.9

4.4

2.9

1.5

1.5
35.0
49.8
63.3
66.9
68.2
68.9
68.9
97.1
na

32.3

40.7

52.8

60.7

66.4

68.6

94.9

na

na
97.8

87.0

69.6

48.4

29.9

18.5

9.2

3.3

na

100.0

89.0

64.7

42.0

20.4

9.0

3.1

na

na

This may itself be of some value, however, in helping in targeting policy interventions on those firms which share the characteristics of cooperating firms but are not currently engaged in cross-border cooperation.

\section{CONCLUSION}

While around a third of all firms in the Republic and Northern Ireland engage in local cooperation, a smaller proportion-one in six in Northern Ireland and one in 12 in the Republic-engage in cross-border cooperation. Firms' participation in both types of networking can be explained in terms of the costs and benefits of each activity, suggesting a range of hypotheses related to the expected returns from cooperation, resource availability and uncertainty. Our results suggest three main reasons why firms in the Republic and Northern Ireland may be more likely to engage in local rather than cross-border cooperation. First, distance from the border does turn out to be a significant factor in determining the probability of cross-border cooperation while it has no effect on the probability of engaging in local cooperation (see also Huber, 2003). This means that cross-border cooperation is less common in areas more distant from the border reducing the overall level of cooperation in the population, particularly in the Republic. Second, in the Republic at least, perceived barriers to cross-border cooperation are discouraging this type of cooperative activity with firms substituting instead more local cooperation. Third, country uncertainty also influences cross-border cooperation with exchange rate uncertainty encourag- 
ing cross-border cooperation, perhaps as a means of currency hedging. In fact, however, the period covered by the survey (2000-02) was a period of relative stability in the Euro-Sterling exchange rate which varied only $+/-2 \%$, following a $7.5 \%$ fall in 1999-2000 and followed by a $10 \%$ appreciation in 2002-03. ${ }^{17}$ It is therefore likely that the relative stability of exchange rates over this period may actually have been reducing the incentives for firms to engage in cross-border cooperation. Resource effects, and the effects of local market uncertainty, are also significant in the estimation but have a broadly similar effect on the probability that firms will engage in cross-border and local cooperation. Essentially similar factors explain the higher incidence of cross-border cooperation in Northern Ireland: a larger proportion of the population firms in Northern Ireland are proximate to the border than in the Republic; and, there is no evidence of any perceived barrier to cross-border cooperation in Northern Ireland as there is in the Republic.

Our results clearly suggest the economic motivations which shape firms' decisions to engage in local and cross-border relationships, and the links between these relationships and firms' other attributes, such as whether or not they have in-house R\&D. In the Republic, too, our results suggest some perceived-although unspecified-barriers to the development of cross-border cooperation, an issue perhaps worthy of further investigation. What is less clear, however, is exactly what further policy actions could be undertaken to boost levels of cross-border cooperation if this is felt to be desirable given the dominance of distance, perceived barriers and country uncertainty in shaping levels of cross-border cooperation. Two avenues are possible, however. First, steps could be taken to increase firms' understanding of crossborder market opportunities and business culture. Our results suggest that this would reduce country uncertainty-in much the same way as participation in crossborder trading would work-and increase the extent of cross-border cooperation. Second, our results suggest that current policy initiatives to increase business $R \& D$ activity in the Republic and Northern Ireland, and to strengthen firms' skill base, are both likely to have indirect benefits in terms of increased cross-border cooperation.

While our study sheds some light on the economic reasons for local and crossborder cooperation in the Republic and Northern Ireland it is subject to a number of important limitations. First, unlike Huber (2003), we have very little information on the organisational forms which firms develop to facilitate cooperation. Huber (2003), for example, considers separately the factors which determine ownership relations, incentive contracts and more informal business relationships, and finds some differences between the determinants of the various forms of cooperation. Second, in our analysis we implicitly assume that the impact of factors such as country uncertainty on firms of different sizes is the same. It is possible, however, that differences in firms' internal resources-in particular the presence of a specialist treasury department in larger firms-may ameliorate the negative effects of currency uncertainty. Future work might consider the importance of these contingent effects.

\footnotetext{
17 The Sterling-Euro exchange rates were: 1999, 0.6587; 2000, 0.6095; 2001, 0.6219; 2002,0.6288; 2003, 0.692. Source: CSO, Dublin
} 
A third limitation of our analysis is its essentially static treatment of the stock of cooperative activity at the time of the survey. As Reuer and Ariño (2002) suggest, cooperative partnerships may often be short-lived and change in nature due either to the firms' competitive environment or internal inconsistency (for example, when there is poor alignment between the governance structure of the cooperative relationship and its functional objectives; Williamson, 1985). One potentially interesting avenue for future research would therefore be to investigate whether the more complex regulatory and market context for cross-border cooperation agreements between firms in the Republic and Northern Ireland means they have shorter duration than similar agreements within a single jurisdiction. ${ }^{18}$ Such an approach may also shed light on the "churn" in firms' cooperative relationships as cooperations develop and dissolve (Reddy et al., 2002).

\section{REFERENCES}

Aulakh, PS, M Kotabe and A Sahay (1996) "Trust and performance in cross-border marketing partnerships: a behavioural approach", Journal of international business studies 27 (5): 1005-32

BMW Regional Assembly (2000) Operational programme for the Border, Midland and Western Region 2000-2006. Longford: Turner Printing

Braczyk, H-J, P Cooke and M Heidenreich, eds (1998) Regional innovation systems: the role of governance in a globalised world. London: UCL

Bradley, J and F Barry (1999) "EMU and Northern Ireland: strategic implications", Irish banking review, Autumn, pp. 12-24

Buckley, PJ and MJ Carter (1999) "Managing cross border complementary knowledge", International studies of management and change 29 (1): 80-104

Buckley, PJ and M Chapman (1997) "The perception and measurement of transaction costs", Cambridge journal of economics 21: 127-45

Buckley, PJ and M Chapman (1998) "The management of cooperative strategies in R\&D and innovation programmes", International journal of the economics of business 5 : 369-81

Cassiman, B and R Veugelers (2002) "Complementarity in innovation strategy: internal $R \& D$, external technology acquisition and cooperation in R\&D", paper presented at European Association for Research in Industrial Economics, Madrid, 5-8 September

Chionis, D and P Liargovas (2002) "An empirical investigation of Greek-Balkan bilateral trade", Eastern European economics 40 (5): 6-32

Cohen, W and D Levinthal (1989) "Innovation and learning: the two faces of R\&D", Economic journal 99: 569-96

\footnotetext{
${ }^{18}$ It is notable, however, that in their analysis of strategic alliances by Spanish firms Reuer and Ariño (2002) found alliance specific (such as age, asset specificity) and firm specific (such as strategy) factors to be more important than environmental change in determining the probability of contractual re-negotiation. Indeed, their results suggested: "no evidence that cross-border ventures are more likely to experience contractual renegotiations than domestic alliances" (Reuer and Ariño, 2002: 62).
} 
Cooke, PN and K Morgan (1998) The associational economy: firms, regions, and innovation. Oxford: Oxford University Press

Fielding, D (2003) "Investment, employment and political conflict in Northern Ireland", Oxford economic papers 55: 512-35

Greene, W (2003) Econometric analysis. Englewood Cliffs, NJ: Prentice Hall

Harris RID and M Trainor (1995) "Innovations and R\&D in Northern Ireland manufacturing: a Schumpeterian approach", Regional studies 29: 593-604

Hewitt-Dundas, N, B Anderson-Callaghan, M Crone, J Murray and S Roper (2002) Learning from the best-knowledge transfers from multinational plants in Ireland-A NorthSouth comparison. Belfast: NIERC/EAC

Huber, P (2003) "On the determinants of cross-border cooperation of Austrian firms with Central and Eastern European partners", Regional studies 37 (9): 947-55

Koopmans, TC (1957) Three essays on the state of economic science. New York: McGraw Hill

Love, JH and S Roper (1999) The determinants of innovation: R\&D, technology transfer and networking effects, Review of industrial organization 15: 43-64

Love, JH and S Roper (2001) "Location and network effects on innovation success: evidence for UK, German and Irish manufacturing plants", Research policy 30: 643-61

Madalla G (1983) Limited-dependent and qualitative variables in econometrics. New York: Cambridge University Press

McCall, C and A Williamson (2000) "Fledgling social partnership in the Irish border region: European Union "community initiatives" and the voluntary sector", Policy and politics 28 (3): $397-410$

McCartney J. and P Teague (1997) "Workplace innovations in the Republic of Ireland", Economic and social review 28: 381-399

Meehan, E (2000) 'Britain's Irish question: Britain's European question?': British-Irish relations in the context of the European Union and the Belfast Agreement", Review of international studies 26 (1): 83-97

Mitko, D, P George, T Stoyan and T Maria (2003) "Cross-border co-operation in Southeastern Europe: the enterprises' point of view", Discussion Paper 9 (2): 17-38 [Department of Planning and Regional Development, School of Engineering, University of Thessaly]

NDP (1999) Ireland national development plan 2000-2006. Dublin: Government Publications

O'Dowd, L, J Corrigan and T Moore (1995) "Borders, national sovereignty and European integration; the British Irish case", Journal of urban and regional research, 19, 2, 27285

Oerlemans, LAG, MTH Meeus and FWM Boekema (1998) "Do networks matter for innovation? The usefulness of the economic network approach in analysing innovation", Tijdschrift voor economische en sociale geografie 89 (3): 298-309

Perkmann, M (2003) "Cross-border regions in Europe-significance and drivers of regional cross-border co-operation", European urban and regional studies 10 (2): 15371 
Petrakos, G and M Tsiapa (2001) "The spatial aspects of enterprise learning in transition countries", Regional studies 35 (6): 549-62

Principe, A (1997) "Technological competencies and products" evolutionary dynamics: a case study from the aero-engine industry", Research policy 25: 1261-76

Reddy, SB, RN Osborn and J-F Hennart (2002) "The prevalence of equity and non-equity cross-border linkages: Japanese investments and alliances in the US", Organisation studies 23 (5): 759-780

Reuer, JJ and A Ariño (2002) "Contractual negotiations in strategic alliances", Journal of management 28 (1): 47-68

Takeishi A (2001) "Bridging inter-and intra-firm boundaries: management of supplier involvement in automobile product development", Strategic management journal 22: 403-33

Tannam, E (1999) Cross-border co-operation in the Republic of Ireland and Northern Ireland. Basingstoke: Macmillan

Veugelers, R. and B Cassiman (1999) "Make and buy in innovation strategies: evidence from Belgian manufacturing firms", Research Policy 28: 63-80

Williams, J, E O'Malley, S Blackwell and S Gorby (2004) Survey of business links in Ireland. Dublin: Economic and Social Research Institute

Wilson, T (2000) "The obstacles to EU regional policy in the Northern Ireland borderlands", Human organisation 59 (1): 1-10

Roper, S (2001) "Innovation, networks and plant location; evidence for Ireland", Regional studies 35 (3): 215-28 